\title{
Pelatihan Pembuatan Ekstrak Curcumin Mix pada Kelompok Ibu Rumah Tangga di Desa Pandian Kabupaten Sumenep
}

\author{
Oleh : \\ Henny Diana Wati $^{1)}$, Purwati Ratna ${ }^{2)}$, Amir Hamzah ${ }^{3)}$ \\ ${ }^{1)}$ Fakultas Pertanian, Universitas Wiraraja, ${ }^{2}$ Fakultas Pertanian, Universitas Wiraraja, \\ ${ }^{3)}$ Fakultas Pertanian, Universitas Wiraraja \\ E-mail : hennydianawati97@gmail.com ${ }^{1)}$
}

\begin{abstract}
Abstrak
Kegiatan ini dilaksanakan dengan latar belakang ingin memberdayakan masyarakat dalam menumbuh kembangkan kreatifitas dan keterampilan dalam mengolah rempah-rempah menjadi ekstrak curcumin mix. Tujuan dari kegiatan untuk membentuk kemandirian secara ekonomi, sehingga tercipta suatu kelompok yang produktif. Ibu rumah tangga merupakan sosok yang sangat vital perannya dalam keluarga dan masyarakat. Pengetahuan yang luas sangat diperlukan oleh ibu-ibu dalam menangani berbagai permasalahan keluarga, termasuk masalah kesehatan. Target kegiatan yang ingin dicapai adalah : (1). Meningkatkan keterampilan keluarga; (2). Menumbuh kembangkan kreatifitas dalam keluarga; (3). Meningkatkan kesehatan keluarga dan (4). Meningkatkan pendapatan dalam keluarga. Bentuk kegiatan ini dilaksanakan dengan menggunakan metode ceramah, diskusi, demonstrasi dengan praktik langsung. Metode ceramah digunakan dalam proses penyampaian materi pelatihan tentang manfaat tanaman rempah-rempah serta cara pembuatan ekstrak curcumin mix. Metode diskusi digunakan sebagai media komunikasi saat pelatihan berlangsung sehingga terjadi komunikasi dua arah antara pemateri dan ibu rumah tangga. Metode demonstrasi digunakan dalam proses memberikan contoh dalam setiap pelatihan, sehingga memberikan kemudahan kepada ibu rumah tangga dalam memahami materi yang disampaikan. Metode praktik langsung digunakan untuk mengaplikasikan materi yang telah didapatkan, tentunya dengan bimbingan pemateri. Hasil yang diperoleh setelah kegiatan ini antara lain 100\% kelompok ibu rumah tangga di Desa Pandian telah mengetahui cara pembuatan ekstrak curcumin mix serta dapat membuat produk ekstrak curcumin mix dengan baik dan layak untuk dipasarkan.
\end{abstract}

Kata Kunci: Pelatihan, Ekstrak, Curcumin Mix, Kesehatan

\section{Pendahuluan}

\section{Analisis Situasi}

Indonesia merupakan negara agraris dengan sumber daya alam yang begitu melimpah. Pemanfaatan dari kekayaan alam tersebut salah satunya adalah penggunaan tanaman herbal untuk tujuan kesehatan secara turun temurun. Saat ini, tanaman rempah banyak dimanfaatkan oleh masyarakat sebagai salah satu cara untuk membantu pencegahan infeksi virus.

Beberapa tanaman herbal yang umum dikonsumsi oleh masyarakat 
adalah temulawak, kunyit, jahe, sereh serta tanaman rempah lainnya.

Menurut Prof. Daryono Hadi Tjahjono, Dekan Sekolah Farmasi, Institut Teknologi Bandung menjelaskan bahwa kunyit (Curcuma longa L) mengandung senyawa metabolit bahan alam berupa kurkumin yang dilaporkan memiliki potensi terapeutik yang beragam seperti antibiotik, antiviral, antioksidan, antikanker, dan untuk penanganan penyakit alzheimer. "Kurkumin (atau turunannya, yaitu kurkuminoid) juga terdapat pada temulawak, jahe, dan tanaman sejenis. Selain senyawa kurkuminoid, terdapat puluhan senyawa kimia lain yang terkandung di dalam tanaman tersebut.

Masyarakat secara umum

memanfaatkan tanaman tersebut dalam kehidupan sehari - hari dan aman dalam penggunaannya. Selain sebagai bumbu masak, tanaman tersebut juga menjadi bahan baku jamu, dan obat herbal terstandarkan.

Secara geografis Desa Pandian merupakan dataran rendah dengan ketinggian 12 mdpl. Luas wilayah Desa Pandian 73,23 Ha dengan jumlah penduduk 4601 jiwa yang tersebar di 3 dusun, yang terdiri dari 20 RT dan 6
RW. Mata pencaharian penduduk Desa Pandian mayoritas bekerja sebagai pedagang. Penduduk di desa ini merupakan penduduk yang memiliki tingkat ekonomi menengah ke bawah. Salah satu program dari PKK Desa Pandian yaitu menanam toga bagi masyarakat yang memiliki pekarangan. Sehingga masyarakat Desa Pandian yang memiliki pekarangan rumah dimanfaatkan untuk menanam buahbuahan dan menanam jenis tanaman rempah seperti temulawak, lengkuas, kencur. kunyit, jahe, serai, daun salam, pandan, dan lain-lain. Tanaman rempah yang ditanam hanya dikonsumsi pribadi sebagai tambahan bumbu masak tanpa mengetahui manfaat serta potensi pemanfaatan tanaman rempah tersebut. Selain dijadikan tambahan dalam bumbu masak, rempah-rempah dapat pula digunakan sebagai bahan untuk membuat minuman tradisional yang dapat menghangatkan tubuh seperti minuman jahe. Masyarakat Desa Pandian belum memiliki keterampilan mengolah rempah-rempah tersebut menjadi produk yang lebih awet dan berkhasiat. Sehingga masyarakat Desa Pandian merupakan kelompok masyarakat yang perlu dilibatkan dalam kegiatan pendidikan dan pelatihan. 
Peningkatan kualitas sumberdaya manusia merupakan langkah penting yang harus terus dilakukan dalam rangka perbaikan kualitas hidup masyarakat agar menjadi lebih sejahtera. Di antara bentuk peningkatan kualitas sumberdaya manusia adalah kegiatan pendidikan dan pelatihan bagi masyarakat guna membentuk masyarakat yang memiliki kepribadian tangguh serta menguasai pengetahuan dan keterampilan yang dapat dimanfaatkan untuk memperbaiki kesejahteraan. Pendidikan dan pelatihan juga berpengaruh terhadap prestasi kerja (Hidayat dan Nurasyiah, 2017).

\section{Permasalahan Mitra}

Potensi Desa Pandian dalam memproduksi tanaman rempah dapat dikatakan cukup besar. Temulawak, kunyit dan sereh merupakan salah satu jenis rempah yang banyak ditanam oleh masyarakat Desa Pandian sebagai tanaman pekarangan. Permasalahan pengolahan rempah-rempah menjadi produk instan yang lebih awet dan berkhasiat oleh masyarakat di Desa Pandian ini dapat diatasi melalui program dari Lembaga Pengabdian kepada Masyarakat Universitas Wiraraja seperti pelatihan dan pendampingan proses pengolahan rempah-rempah menjadi produk instan berupa ekstrak curcumin mix. Masyarakat di Desa Pandian belum mengenal proses pengolahan rempahrempah menjadi produk instan. Selama ini rempah-rempah hanya dimanfaatkan secara tradisional menjadi minuman penghangat badan. Mereka belum memiliki keterampilan mengolah rempah-rempah tersebut menjadi produk yang lebih awet dan berkhasiat yaitu produk instan berupa ekstrak curcumin mix.

\section{Metode Pelaksanaan}

Pada kegiatan pengabdian kepada masyarakat Program Kemitraan Masyarakat pada kelompok ibu rumah tangga Desa Pandian, digunakan menggunakan metode ceramah, diskusi, demonstrasi dengan praktik langsung.

1. Metode ceramah digunakan dalam proses penyampaian materi pelatihan, dengan pemberian teori tentang manfaat tanaman rempahrempah serta cara pembuatan ekstrak curcumin mix.

2. Metode diskusi digunakan sebagai media komunikasi saat pelatihan berlangsung sehingga terjadi 
komunikasi dua arah antara pemateri dan ibu rumah tangga.

3. Metode demonstrasi digunakan dalam proses memberikan contoh dalam setiap pelatihan, sehingga memberikan kemudahan kepada ibu rumah tangga dalam memahami materi yang disampaikan.

4. Metode praktik langsung digunakan untuk mengaplikasikan materi yang telah didapatkan, tentunya dengan bimbingan pemateri. Selanjutnya dilakukan proses pendampingan produksi, pengemasan, pelabelan dan pemasaran produk ekstrak curcumin mix. Pemasaran dilakukan melalui media sosial dan juga pada saat ada pameran yamg dapat dijadikan produk unggulan Desa Pandian.

5. Evaluasi hasil kegiatan dilakukan dengan cara memberikan angket yang berisi pertanyaan/pernyataan tentang seputar produk ekstrak curcumin mix kepada sasaran dalam bentuk pilihan ganda.

\section{Hasil Dan Pembahasan}

Hasil dan pembahasan serta yang diperoleh selama kegiatan pengabdian kepada masyarakat melalui kelompok ibu rumah tangga ini antara lain :

\section{Pengetahuan masyarakat tentang tanaman rempah menjadi Ekstrak}

\section{Curcumin mix}

Penyuluhan cara pemanfaatan tanaman rempah menjadi ekstrak curcumin mix dilakukan dengan membagikan leaflet yang berisi alat dan bahan, cara pembuatan, serta manfaat. Kegiatan penyuluhan diawali dengan penyampaian materi oleh tim narasumber kepada masyarakat sasaran, agar sasaran dapat mengetahui materi tentang bahan dan produk yang akan dibuat. Melalui penyampaian materi ini, narasumber memberikan informasi tentang tanaman rempahrempah, khususnya temulawak, kunyit, jahe, dan sereh yang dibutuhkan dalam pembuatan ekstrak curcumin mix, proses pembuatan ekstrak curcumin mix, manfaat tanaman rempah yang ditanam dalam pekarangan, dapat dijadikan peluang untuk menjadikan ekstrak curcumin mix sebagai alternatif usaha rumah tangga.

Sebelum materi disampaikan oleh narasumber, pada kegiatan ini terlebih dahulu dilakukan penilaian tingkat pengetahuan sasaran melalui 
Jurnal Abdiraja

ISSN : 2621-9379 (Online)

Volume 4, Nomor 2, September 2021

pengisian angket/instrumen pre-test.

Instrumen pre-test berisi pertanyaan tentang materi dan harus dijawab oleh sasaran kelompok ibu rumah tangga.

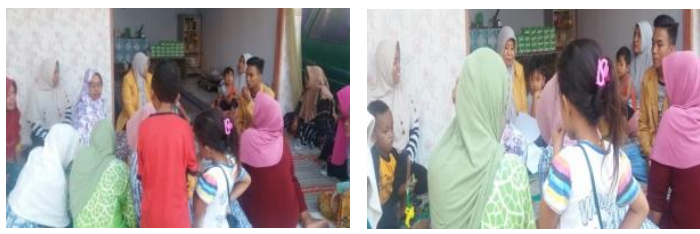

Gambar 1. Penyuluhan cara pemanfaatan tanaman rempah menjadi ekstrak curcumin mix

Hasil evaluasi pre test dari pemahaman sasaran kelompok ibu rumah tangga terhadap pembuatan ekstrak curcumin mix (Tabel 1) menunjukkan bahwa sebelum adanya pelatihan 100\% sasaran kelompok ibu rumah tangga belum mengetahui cara pembuatan ekstrak curcumin mix dan belum pernah membuat ekstrak curcumin mix $88,89 \%$ belum mengetahui bahan yang akan digunakan untuk ekstrak curcumin mix. Disamping itu, $86,67 \%$ belum mengetahui manfaat tanaman rempah sebagai apotik hidup.Setelah adanya penyuluhan, 100\% kelompok ibu rumah tangga telah mengetahui cara pembuatan ekstrak curcumin mix serta 93,33\% kelompok ibu rumah tangga telah mengetahui manfaat tanaman rempah sebagai apotek hidup (Tabel 2).

Tabel 1. Hasil Pre-Test Pemahaman Kelompok Ibu Rumah Tangga Terhadap Pembuatan Ekstrak Curcumin mix

\begin{tabular}{|l|c|c|}
\hline \multicolumn{1}{|c|}{ Pertanyaan } & \multicolumn{2}{|c|}{ Jawaban (\%) } \\
\cline { 2 - 3 } & Ya & Tidak \\
\hline $\begin{array}{l}\text { Apakah anda mengetahui } \\
\text { alat dan bahan untuk } \\
\text { membuatekstrak curcumin } \\
\text { mix? }\end{array}$ & 0 & 100 \\
\hline $\begin{array}{l}\text { Apakah anda mengetahui } \\
\text { cara pembuatan ekstrak } \\
\text { curcumin mix ? }\end{array}$ & 0 & 100 \\
\hline $\begin{array}{l}\text { Apakah anda mengetahui } \\
\text { tanaman rempah yang dapat } \\
\text { digunakan untuk membuat } \\
\text { ekstrak curcumin mix? }\end{array}$ & 11,11 & 88,89 \\
\hline $\begin{array}{l}\text { Apakah anda pernah } \\
\text { membuat ekstrak curcumin } \\
\text { mix sendiri dirumah? }\end{array}$ & 0 & 100 \\
\hline $\begin{array}{l}\text { Apakah anda mengetahui } \\
\text { manfaat tanaman rempah } \\
\text { sebagai apotek hidup? }\end{array}$ & 13,33 & 86,67 \\
\hline
\end{tabular}

Tabel 2. Hasil Post-Test Pemahaman Kelompok Ibu Rumah Tangga Terhadap Pembuatan Ekstrak Curcumin mix

\begin{tabular}{|l|c|c|}
\hline \multicolumn{2}{|c|}{ Pertanyaan } & \multicolumn{2}{|c|}{ Jawaban (\%) } \\
\cline { 2 - 3 } & Ya & Tidak \\
\hline $\begin{array}{l}\text { Apakah anda mengetahui } \\
\text { alat dan bahan untuk }\end{array}$ & 100 & 0 \\
$\begin{array}{l}\text { membuat ekstrak curcumin } \\
\text { mix? }\end{array}$ & & \\
\hline $\begin{array}{l}\text { Apakah anda mengetahui } \\
\text { cara pembuatan ekstrak } \\
\text { curcumin mix? }\end{array}$ & 100 & 0 \\
\hline
\end{tabular}


Jurnal Abdiraja

ISSN : 2621-9379 (Online)

Volume 4, Nomor 2, September 2021

\begin{tabular}{|c|c|c|}
\hline $\begin{array}{l}\text { Apakah anda mengetahui } \\
\text { tanaman rempah yang } \\
\text { digunakan untuk membuat } \\
\text { ekstrak curcumin mix? }\end{array}$ & 100 & 0 \\
\hline $\begin{array}{l}\text { Apakah anda pernah } \\
\text { membuat ekstrak curcumin } \\
\text { mix sendiri dirumah? }\end{array}$ & 66,67 & 33,33 \\
\hline $\begin{array}{l}\text { Apakah anda mengetahui } \\
\text { manfaat tanaman rempah } \\
\text { sebagai apotek hidup? }\end{array}$ & 93,33 & 6,67 \\
\hline
\end{tabular}

dilakukan oleh narasumber untuk setiap tahap.

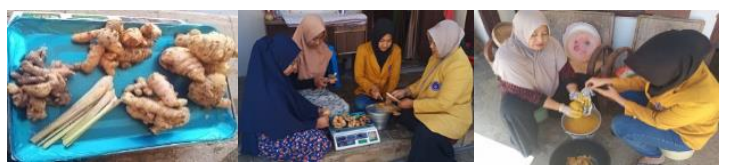

Gambar 2. Penyiapan bahan dan pembuatan ekstrak curcumin mix

Pada tahap pemasakan

(Gambar 3), beberapa peserta mencoba

\section{PelatihanPembuatanEkstrak}

\section{Curcumin Mix}

Pelatihan pembuatan ekstrak curcumin mix dilakukan dengan cara demonstrasi pembuatan ekstrak curcumin mix dilaksanakan setelah penyampaian materi selesai dilakukan. Pada kegiatan demonstrasi, narasumber terlebih dahulu mengenalkan bahan baku yang digunakan disertai dengan jumlah atau berat masing-masing bahan. Narasumber juga menyampaikan proses apa saja yang dilakukan dalam pembuatan ekstrak curcumin mix serta alat-alat yang digunakan. Menurut narasumber, proses pembuatan ekstrak curcumin mix meliputi 4 tahap, yaitu penyiapan bahan, pembuatan ekstrak curcumin (temulawak, kunyit, jahe serta sereh), pemasakan, dan penghalusan serbuk. Demonstrasi

disaksikan oleh peserta lainnya. Hal ini dimaksudkan untuk memberikan pengalaman langsung kepada kelompok ibu rumah tangga dalam proses pembuatan produk, sehingga kelompok tersebut memiliki sikap percaya diri yang tinggi ketika membuat sendiri produk

Gambar 3. Pemasakan ekstrak curcumin mix

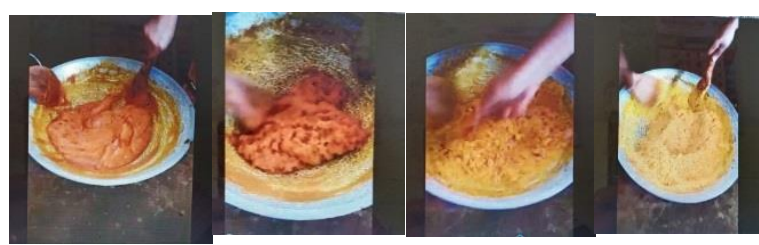

Gambar 4. Pengkristalan ekstrak curcumin mix
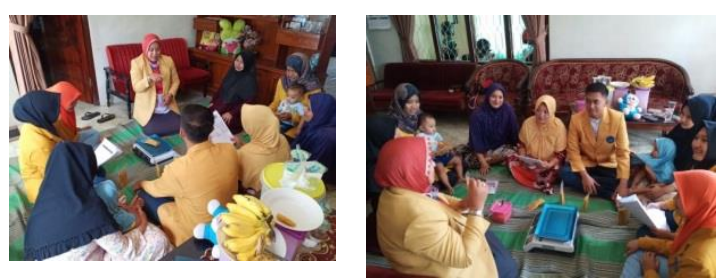

Gambar 5. Pengemasan ekstrak curcumin mix
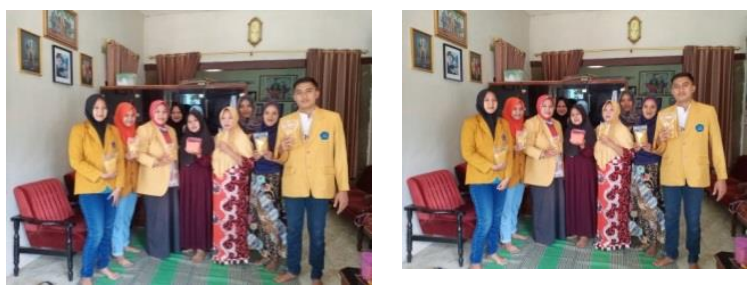
Jurnal Abdiraja

ISSN : 2621-9379 (Online)

Volume 4, Nomor 2, September 2021

Gambar 6. Foto bersama dengan kelompok ibu rumah tangga

Selama kegiatan berlangsung, kelompok ibu rumah tangga terlihat sangat antusias. Hal ini ditunjukkan dari beberapa pertanyaan yang diajukan pada saat pelatihan berlangsung. Pelatihan pembuatan ekstrak curcumin mix dimulai dengan mempersiapkan bahan-bahan yang dibutuhkan (Gambar 2), diikuti dengan pemasakan (Gambar 3), Pengkristalan (Gambar 4) dan pengemasan ekstrak curcumin mix (Gambar 5), sampai foto bersama setelah kegiatan pelatihan selesai (Gambar 6).

Selama proses pelatihan pembuatan ekstrak curcumin mix, Tim Pengabdian Masyarakat Universitas Wiraraja menilai keterampilan kelompok ibu rumah tangga dalam membuat ekstrak curcumin mix, seperti yang ditunjukkan pada Tabel 3 . Berdasarkan hasil penilaian, Kelompok ibu rumah tangga dinilai telah dapat membuat dan mengemas ekstrak curcumin mix dengan sangat baik. Keterampilan ini diharapkan mampu digunakan mitra dalam proses produksi dan pemasaran ekstrak curcumin mix dalam acara Pameran di Kabupaten Sumenep
Tabel 3. Hasil Penilaian Keterampilan Pembuatan Ekstrak Curcumin Mix

\begin{tabular}{|l|l|}
\hline \multicolumn{1}{|c|}{ Komponen yang diamati } & \multicolumn{1}{|c|}{ Penilaian } \\
\hline $\begin{array}{l}\text { Persiapan bahan-bahan ekstrak } \\
\text { curcumin mix }\end{array}$ & Sangat Baik \\
\hline $\begin{array}{l}\text { Pembuatan ekstrak curcumin } \\
\text { mix }\end{array}$ & Baik \\
\hline $\begin{array}{l}\text { Penyaringan ekstrak curcumin } \\
\text { mix }\end{array}$ & Baik \\
\hline $\begin{array}{l}\text { Pengemasan ekstrak curcumin } \\
\text { mix }\end{array}$ & Sangat Baik \\
\hline
\end{tabular}

3. Pendampingan Produksi dan Pemasaran Ekstrak Curcumin Mix

Kegiatan Pengabdian kepada masyarakat dilanjutkan dengan pendampingan produksi dan Pemasaran ekstrak curcumin mix. Kelompok ibu rumah tangga di Desa Pandian secara mandiri membuat produksi ekstrak curcumin mix (Gambar 7). Hasil dari ekstrak curcumin mix ini, selanjutnya dikemas serta dipasarkan.
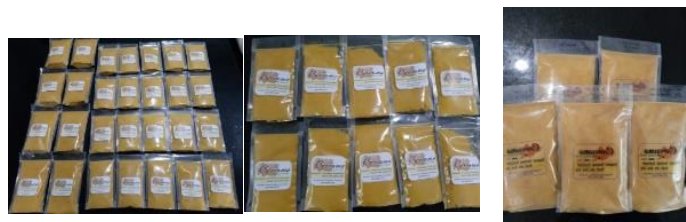

Gambar 7. Ekstrak curcumin mix siap dipasarkan

\section{Kesimpulan}




\begin{abstract}
Kegiatan pelatihan tentang pembuatan ekstrak curcuma mix bagi kelompok ibu rumah tangga di Desa Pandian telah terlaksana dengan baik dan berhasil meningkatkan pemahaman kelompok ibu rumah tangga terhadap pembuatan ekstrak curcuma mix yang ditunjukkan dengan $100 \%$ kelompok ibu rumah tangga mengetahui cara pembuatan ekstrak curcumin mix. Pelatihan pembuatan ekstrak curcumin mix meningkatkan ketrampilan mitra yang ditunjukkan dengan kelompok ibu rumah tangga dapat membuat ekstrak curcumin mix dengan baik dan mengemas ekstrak curcumin mix dengan sangat baik. Pendampingan produksi ekstrak curcumin mix telah berhasil dilakukan yang ditunjukkan dengan adanya produk ekstrak curcumin mix.
\end{abstract}

\section{Ucapan Terima Kasih}

Ucapan terima kasih disampaikan kepada Kepala Desa dan Masyarakat Desa Pandian Kec. Kota Sumenep Kab. Sumenep yang telah berpartisipasi aktif dalam kegiatan ini serta Universitas Wiraraja yang telah membiayai pelaksanaan kegiatan pengabdian kepada masyarakat ini.

\section{DaftarPustaka}

BPS, 2018, Kecamatan Kota Sumenep Dalam Angka 2017, BPS Kabupaten Sumenep.

Hidayat dan Nurasyiah. 2017. Pengaruh Diklat (Pendidikan Dan Pelatihan) Terhadap Prestasi Kerja Karyawan di Bank Bpr Rokan Hulu. Jurnal Ilmiah Cano Ekonomos 6(1):71-82

https://www.itb.ac.id/news/read/57446/ho me/manfaat-kunyit-dan-temulawakterhadap-penanganan-covid-19 


\section{Jurnal Abdiraja}

ISSN : 2621-9379 (Online)

Volume 4, Nomor 2, September 2021 